\title{
Fire load survey in multi-storey wholesale premise - a case study
}

\author{
${ }^{I *}$ Nurud, S. S., ${ }^{1}$ Abdullah, I., ${ }^{2}$ Saari, M., ${ }^{2}$ NorMariah, A. and ${ }^{2}$ Rafee, $B$. \\ ${ }^{1}$ Faculty of Engineering Technology, \\ University Malaysia Pahang, Tun Razak Highway, 26300 Kuantan, Pahang, MALAYSIA. \\ ${ }^{2}$ Department of Chemical Engineering and Environmental, \\ Faculty of Engineering, University Putra Malaysia,43400 Serdang, Selangor, MALAYSIA \\ *Email: nurud@ump.edu.my
}

\begin{abstract}
A combustible material is one of fire hazard where the amount of combustible materials or fire load could affect the heat release and fire severity in enclosure. The fire severity in the context of fire load is related to intensity and duration of fire in enclosure. Fire load survey is conducted in this study to estimate the amount of combustible materials in wholesale premise since it become threat to life safety and property loss. The determinations of fire load in 3-storey wholesale premise in Kuantan city is conducted by using combination fire load survey method; weighing and inventory method. Result from fire load survey can help to determine the sufficient requirements of fire suppression in premise as well as fire fighters intervention strategy. An extension of this study, the data could be used as an important input to design fire for deterministic analysis in fire risk assessment to quantify the level of fire risk towards life, property and environment.
\end{abstract}

Indexed Terms- fire load, combustible material, wholesale.

\section{INTRODUCTION}

Due to growing of cost living and household domestic use nowadays, large-scale wholesale market had been developed rapidly. There are lots of various good is sold including groceries, textile, hardware, plastic ware or cleaning product which were stacked together and most of these goods are combustible material. Since this premise attracted a large number of customers, due to its specific environment and arrangement, these situations creates a great fire risk in this kind of large architecture where it will cause a large number of casualties, huge economic losses and adverse impact to social community. Everyone knows that fires could happen but nobody knows exactly when or where a fire will occur, under what conditions, and who will be at risk because one cannot predict the future. For this issue, fire engineers had found one way to determine whether such a potential exist by undertaking a fire risk assessment of the building or facility. Identification of fire hazard is a crucial step in qualitative or quantitative fire risk assessment to determine the fire risk in a building or compartment. Fire hazard might include combustible materials and ignition sources where the extent of these hazards depends on a few factors [1]. Amount of combustible hazard is one of the factors that could describe the severity of the fire hazard and commonly translated as fire load, Q [2] [3].

Another study done by SFPE [4] and supported by previous researcher, Cheng and Hadjisophocleous [5] had concluded beside fire load, the fire growth to fully developed fire in enclosure also depends on geometry and ventilation conditions of the compartment, and availability of fire suppression. Fire load is defined as total heat energy (MJ) that can be released through complete combustion and often expressed as energy density per unit floor area, Q" $\left(\mathrm{MJ} / \mathrm{m}^{2}\right)$ which indicate the total heat energy per area that will be released through complete combustion of all combustible within a compartment [2][6].

Fire Load, $\mathrm{Q}=$ sum of all combustible mass in compartment $(\mathrm{kg}) \times$ calorific value of combustible $(\mathrm{MJ} / \mathrm{kg})$ 
Fire Load Density, Q" = sum of all combustible mass in compartment $(\mathrm{kg}) \times$ calorific value of combustible $(\mathrm{MJ} / \mathrm{kg}) /$ floor area of compartment $\left(\mathrm{m}^{2}\right)$

More studies had been done on fire load in residential [7] [2] [8] [9], office [10] [11], shopping complex [12][13], commercial building [14] [6], green building [15], high rise [16] [17], and educational building [3]. In this paper, a result on fire load and density will be presented for wholesale premise which is rarely discussed to give a view on how severe a fire could growth and adopted fire protection to reduce the losses. The result from this study to some extent could assist the fire fighters team to prepare with suitable fire fighting equipment and strategies as well as provide information for the pre-caution of fire risk among occupants.

\section{METHODOLOGY}

Fire load is determined by carrying out fire load survey using different method including questionnaire, weighing, inventory, combination of weighing and inventory, and web-viewing [11]. Inventory technique is the famous survey method and had been used since 1970s to survey fire load in office building and hospital [2]. In addition, the author claims the inventory technique is convenient, acceptable to residents and also time saving during fire load survey of randomly selected residential building in the city of Kanpur. It different with Liu \& Chow (2014), [9] where they had suggest questionnaire technique as a good choice since it is time saving and cause fewer disturbance to the occupants in residential building while web viewing need further validations.

Finding from study done on assessment of the impact of fire load survey methodology on design fire, the combination method of weighing and inventory has been considered as the most appropriate fire or fuel load survey method [18], thus it has been chosen for this study as it also had been used by most of researchers in fire safety [7] [6][3]. The building selected for this study is 3 storeys wholesale premise which is located in Kuantan, an urban area in Pahang, Malaysia. This premise generally is selling household items such as curtain, towel, blanket, plastic container, dry food, hardware and so on.

In order to calculate the fire load, as this particular building did not install a wall to separate the compartment, the area with fire load in this premise were categorized as first level, second level and third level. Nevertheless, the combustible materials considered as textile, plastic ware, wood or flammable liquids[1] which were stacked together on the rack and generate huge fire load. In order to simplify the fire load estimation, assumption has been made by Eduful in 2012 [11];

- Combustible materials are uniformly distributed throughout the building

- All combustible materials (except in enclosure) in fire area would undergo total combustion

Fire load calculated by using weighing method is based on measured weight of combustible material multiply with its corresponding calorific value as shown in Equation 1. Weights of items can be obtained by directly weighted the items or pre-weighed items. The calorific value of different items and materials are presented in Table 1.

Table 1: Calorific value of combustible materials in wholesale premise

\begin{tabular}{llll}
\hline \multicolumn{1}{c}{ Material } & \multicolumn{1}{c}{ Calorific value (MJ/kg) } & Reference \\
\hline Plastic ware & 43.5 & {$[19]$} & \\
Textiles & 18.8 & {$[3]$} \\
Wood & 18.6 & {$[3]$} \\
Flammable liquid & 37 & {$[20]$} & \\
\hline
\end{tabular}

For the large and heavy items, the weights are obtained by using measured volume $\left(\mathrm{m}^{3}\right)$ of items multiply by its density to calculate fire load. In case of irregular shape of object, the volume of $98 \%$ of all items within compartment could be measured [11]. Table 2 shows the density of different materials used in this study. 
Table 2: Density of different materials

\begin{tabular}{lll}
\hline Material & Density & Reference \\
\hline Plasticware & $1050 \mathrm{~kg} / \mathrm{m}^{3}$ (polystyrene) & {$[20]$} \\
& $850 \mathrm{~kg} / \mathrm{m}^{3}$ (polypropylene) & \\
Textiles & $1550 \mathrm{~kg} / \mathrm{m}^{3}$ (cotton) & {$[20]$} \\
& $1480 \mathrm{~kg} / \mathrm{m}^{3}$ (polyester) & \\
Wood & $450 \mathrm{~kg} / \mathrm{m}^{3}$ & {$[21]$} \\
Flammable liquid & $950 \mathrm{~kg} / \mathrm{m}^{3}$ & {$[22]$} \\
\hline
\end{tabular}

Fire loads were calculated from the masses of the items with their corresponding calorific value as similar as weighting method. Meanwhile, for the calculation of fire load density $\left(\mathrm{MJ} / \mathrm{m}^{2}\right)$ in Equation 2 , the area of each level is measured. Fire loads divided into two categories; fixed fire load and movable fire load. Cabinet, wall, ceiling and floor are classified under fixed fire load while goods for selling considered as moveable fire load.

\section{RESULT AND DISCUSSION}

\subsection{Fire load distribution}

Building consist variety of combustible materials as fire load and it characteristic is highly depend on occupancy and building use where the mean and maximum fire load is decreased as compartment area increased. Wood and couch is the biggest proportion of fire load characteristic in hotel especially in reception area and guest room, while paper and wood are the major contributor for office even though it slowly reduces due to usage of internet in spreading information, whereas in shopping mall wood and textiles are the main combustible materials [7], and as reported by Chow \& Chow, (2010) [23] residential consist flammable liquid/gases and wood in kitchen as a major fire load. The fire load in 3 levels wholesale premise with area $546 \mathrm{~m}^{2}$ for each level compromise several combustible materials with different heat of combustion. Each level consist of different items where first level is for hardware, glasses and dry food/beverage, second level loading with kitchen utensils and electrical appliances while third level consist of household items such as towel, curtain, plasticware, cleaning tools, toys and shoes. The contribution of different materials to the total combustible content is presented in Table 3.

Table 3: Contribution of different combustible materials to the total fire load

\begin{tabular}{|c|c|c|c|c|c|}
\hline \multirow[t]{2}{*}{ Material } & \multirow[t]{2}{*}{ Units } & \multicolumn{3}{|c|}{ Mean } & \multirow{2}{*}{$\begin{array}{c}\% \% \\
\text { Contribution }\end{array}$} \\
\hline & & $\begin{array}{l}\text { Fixed fire } \\
\text { load }\end{array}$ & $\begin{array}{c}\text { Movable fire } \\
\text { load }\end{array}$ & Total fire load & \\
\hline \multirow[t]{3}{*}{ Plasticware } & $\mathrm{kg}$ & 150 & 5370 & 5520 & 50.23 \\
\hline & MJ & 3300 & 19130 & 195230 & \\
\hline & $\mathrm{MJ} / \mathrm{m}^{2}$ & 6.04 & 351.52 & 357.56 & \\
\hline \multirow[t]{3}{*}{ Textiles } & $\mathrm{kg}$ & - & 2700 & 2700 & 24.57 \\
\hline & MJ & - & 48320 & 48320 & \\
\hline & $\mathrm{MJ} / \mathrm{m}^{2}$ & - & 88.50 & 88.50 & \\
\hline \multirow[t]{3}{*}{ Wood } & $\mathrm{kg}$ & 900 & 1120 & 2020 & 18.38 \\
\hline & MJ & 17100 & 19616 & 36716 & \\
\hline & $\mathrm{MJ} / \mathrm{m}^{2}$ & 31.32 & 35.93 & 67.25 & \\
\hline \multirow[t]{3}{*}{ Flammable liquid } & $\mathrm{kg}$ & 150 & 600 & 750 & 6.82 \\
\hline & MJ & 4450 & 22500 & 26950 & \\
\hline & $\mathrm{MJ} / \mathrm{m}^{2}$ & 8.15 & 41.21 & 49.36 & \\
\hline
\end{tabular}

The survey is conducted by dividing the fire load into fixed and moveable fire load. Result from fire load survey shows higher contribution of fire load in corresponding premise is plasticware $(50.23 \%)$ 
including food container, basket, toys and kitchen appliances, then followed by textiles $(24.57 \%)$, wood (18.38\%) and finally flammable liquid. All goods are stacked together and overlapping up to a ceiling. For stability purpose, the use of steel as a structure of the rack is installed directly from the floor surface up to the ceiling. Therefore, instead of wood the ceiling is cemented to slab. This is the reason of less distribution of wood as fire load in this premise as compared to other buildings [7] [23].

\subsection{Fire load density (FLD)}

Fire load density (FLD) represent the severity of fire in terms of its tendency of area or building fire reach fully developed fire in specific duration. The duration of a fully-developed fire mainly depends on the amount of fire load in the enclosure and the fire burning rate [20]. Office building with FLD $520 \mathrm{MJ} / \mathrm{m}^{2}$ literally could reach fully developed fire with 90 minutes of burning duration after ignition [16] while compartment with $680 \mathrm{MJ} / \mathrm{m}^{2}$ of FLD (wood) burned for almost 110 minutes [24]. Higher value of fire load caused longer burning duration, thus resulted in higher potential of property's damage [9] and structure liability [24]. Hence it is crucial to estimate and control the loading of combustible materials as a fire load in building. Previous researchers had concluded average FLD for residential is $500 \mathrm{MJ} / \mathrm{m}^{2}$ [25], high rise residential $1400 \mathrm{MJ} / \mathrm{m}^{2}$ due to small average living area [13][9], hotel $560 \mathrm{MJ} / \mathrm{m}^{2}$ [6], office range from $348 \mathrm{MJ} / \mathrm{m}^{2}$ to $1321 \mathrm{MJ} / \mathrm{m}^{2}$ [26] and shop $600 \mathrm{MJ} / \mathrm{m}^{2}$. Small area of compartment could increase the value of FLD. A summary of FLD in each level is shows in Figure 1.

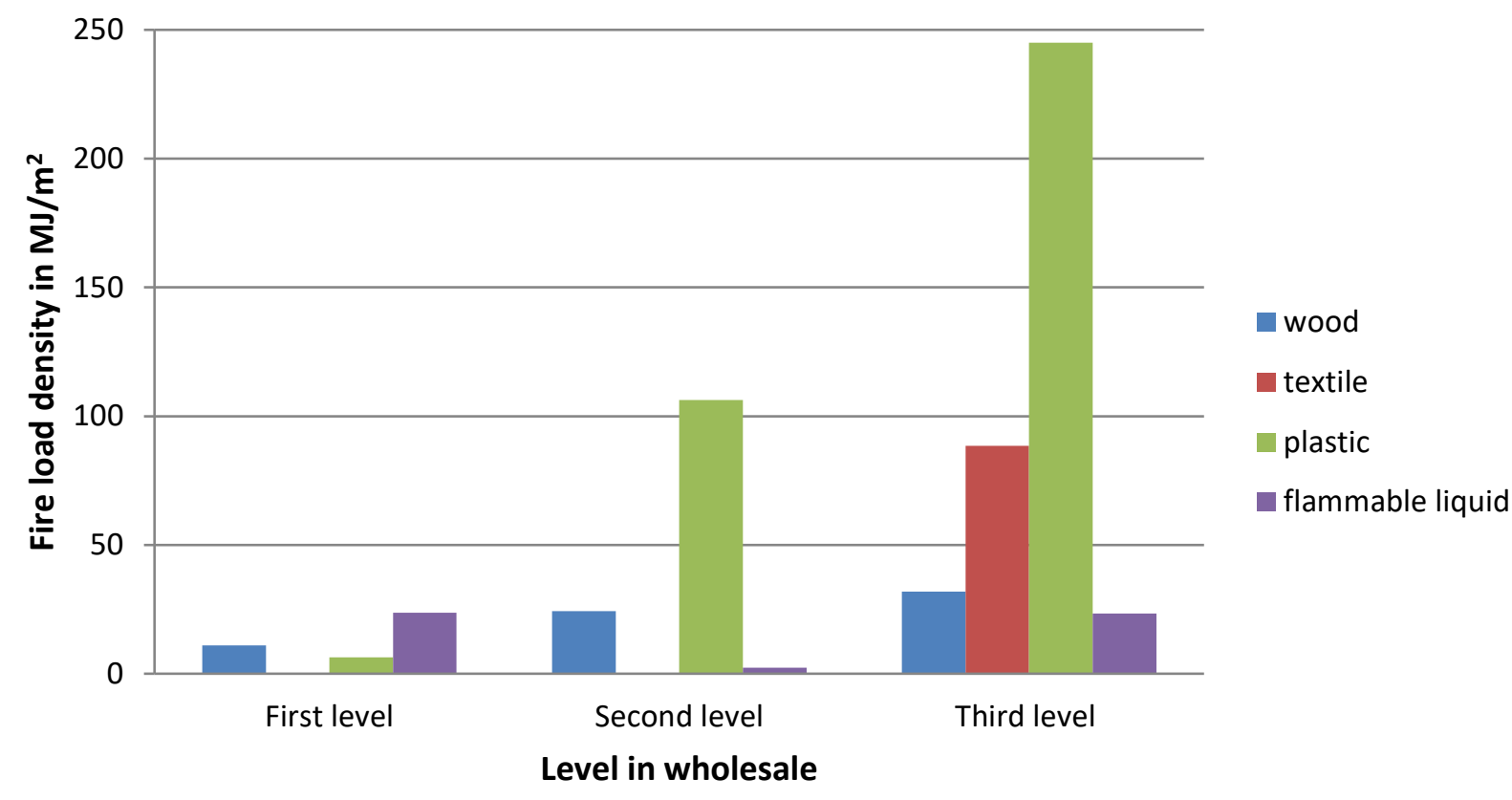

Figure 1: Fire load density at each level in wholesale premise

The values of FLD at each level were found to be varying depending on the nature and amount of material stored. The maximum value was $388.66 \mathrm{M} / \mathrm{m}^{2}$ for the third level and the minimum value was $41.45 \mathrm{MJ} / \mathrm{m}^{2}$ for the first level. This is expected as third level consist of large number of plastic ware which added to the fire load while first floor had less combustible materials since it loaded with dry food/beverage, glasses and hardware. In this study, FLD for wholesale premise with total area 1638 $\mathrm{m}^{2}$ is estimated to be $563 \mathrm{MJ} / \mathrm{m}^{2}$. This value is comparable with Barnett's study on shop (home furnishing) in 1984, where the FLD of $2284 \mathrm{~m}^{2}$ is estimated to be $550 \mathrm{MJ} / \mathrm{m}^{2}$ [20].

\subsection{Fire risk reduction}

Recent studies had discovered, beside amount of combustible, the location of fire load [27], opening, ventilation and suppression might influenced the fire growth. Smoke actuation times is shorter for two open door than single open door in compartment due to more air supply generates larger fire and 
smoke [28]. Based on fire load survey result, there are three main approaches of risk reduction as discussed by Ramachandran \& Charters (2011) [1];

i) Reduce the hazard

ii) Reduce the frequency

iii) Reduce the consequences

Amount of combustible materials and arrangement of these objects are necessary risk associated with fire load. In the event that fire load placed at the corner of the compartment, the wall and nearby furniture is ignited which ultimately generate radiation feedback to encourage the fire growth. Minimizing the fire load in compartment as well as keep an adequate distance between easily ignited fire loads are some of measures that could be taken in reducing the risk from the hazard.

Housekeeping, regular inspection and periodic maintenance of fire system are some of mitigation measures that are helpful to reduce the frequency of severe fire events. In terms of risk control, these measures are considered administrative control. Trained and competent person is needed for maintenance where special attention is required while identifying a fire hazard during housekeeping or inspection. Ventilation with low velocities and appropriate fire suppression could reduce the growth and spread of fire in most of fire events.

Introducing additional mitigation measure e.g active or passive system or improving the reliability of existing measure e.g more sensitive alarm systems were other approaches to reduce the severity of consequences. Fire sprinkler installation could reduce the severity by reducing the temperature and extinct fire spread. Separating compartment or easy ignited fire load with high-rated fire resistance wall could also reduce the fire severity [29]. In addition, type of fire extinguisher suggested for this premise is $\mathrm{ABC}$ Dry Powder since this type of extinguisher suitable for Class A (ordinary combustible), Class B (liquids) and C (gases).

\section{CONCLUSION}

Fire load in 3-storeys wholesale premise of household items in Kuantan city is surveyed. The result of FLD were analysed and the observations are summarized below.

- The fire load densities obtained for corresponding wholesale premise ranges from 41.45 $\mathrm{MJ} / \mathrm{m}^{2}$ to $388.66 \mathrm{MJ} / \mathrm{m}^{2}$. In view of highest calorific value from Table 1, high amount of plastic contribute to a higher FLD $\left(357.6 \mathrm{MJ} / \mathrm{m}^{2}\right)$.

- Total fire load density was $563 \mathrm{MJ} / \mathrm{m}^{2}$ which is comparable with previous research done by Barnett (1984) [19], $550 \mathrm{MJ} / \mathrm{m}^{2}$.

- Risk reduction strategies comprises of hazard reduction, frequency reduction and consequences reduction.

- Reduce the amount of fire load; regular inspection and installation of fire wall are examples of risk reduction for fire event.

- The result of fire load survey could assist the engineer to better estimate the likely fire severity, and thus help to provide adequate and cost effective fire protection for example the used of materials to construct the storage area and installation of fire control measures that were designed adequately against the heat generated.

- Fire load could be used by fire-fighters to identify the most vulnerable or dangerous area in fire building for fire service intervention and give and idea on how likely the fire will spread from one area to another.

\section{REFERENCES}

[1] G. Ramachandran and D. Charters, Quantitative Risk Assessment in Fire Safety. London, United Kingdom: Taylor \& Francis LTD, 2011.

[2] S. Kumar and C. V. S. K. Rao, "Fire load in residential buildings," Build. Environ., vol. 30, no. 2, pp. 299-305, Apr. 1995.

[3] P. R. Shrivastava and P. H. Sawant, "Estimation of Fire Loads for an Educational Building - A 
Case Study," Int. J. Sci. Eng. Technol., vol. 391, no. 2, pp. 388-391, 2013.

[4] SFPE, SFPE (Society of Fire Protection Engineers), 3rd Editio. Bethesda, MD, USA,: Society of Fire Protection Engineers., 2002.

[5] H. Cheng and G. V. Hadjisophocleous, "Dynamic modeling of fire spread in building," Fire Saf. J., vol. 46, no. 4, pp. 211-224, May 2011.

[6] N. Ocran, "Fire loads and design fires for mid-rise buildings," Carleton University, 2012.

[7] C. Thauvoye, B. Zhao, J. Klein, and M. Fontana, "Fire Load Survey and Statistical Analysis," in Fire Safety Science Proceedings of the Ninth International Symposium, 2008, vol. 9, pp. 991-1002.

[8] S.-H. Wu, "The Fire Safety Design of Apartment Buildings," University of Canterbury, 2001.

[9] J. Liu and W. K. Chow, "Determination of Fire Load and Heat Release Rate for High-rise Residential Buildings," Procedia Eng., vol. 84, pp. 491-497, 2014.

[10] C.-J. Chen, W.-D. Hsieh, W.-C. Hu, C. Lai, and T.-H. Lin, "Experimental investigation and numerical simulation of a furnished office fire," Build. Environ., vol. 45, no. 12, pp. 27352742, Dec. 2010.

[11] J. Eduful, "Correlation of fire load survey methodologies towards design fires for office buildings," Carleton University, 2012.

[12] C. C. S. Fong, "Fire Risk Factors in Shopping Malls," Int. J. Eng. Perform. Based Fire Codes, no. 1, pp. 21-28, 2008.

[13] C. C. . Fong and W. . Chow, "Fire Load Density Survey in Four Shopping Malls in Hong Kong," Int. J. Eng. Perform. Based Fire Codes, vol. 10, no. 1, pp. 12-16, 2011.

[14] G. Chu and J. Sun, "Decision analysis on fire safety design based on evaluating building fire risk to life," Saf. Sci., vol. 46, no. 7, pp. 1125-1136, Aug. 2008.

[15] K. Livkišs, "Fully developed fires in low energy and energy efficient " buildings," Lund University, Sweden, 2012.

[16] W. K. Chow, S. S. Han, and H. Kong, "REPORT ON A RECENT FIRE IN A NEW CURTAIN-WALLED BUILDING,” vol. 8, no. 3, pp. 84-87, 2006.

[17] X. Sun and M. Luo, "Fire Risk Assessment for Super High-rise Buildings," Procedia Eng., vol. 71, pp. 492-501, 2014.

[18] E. Zalok and J. Eduful, "Assessment of fuel load survey methodologies and its impact on fire load data,” Fire Saf. J., vol. 62, pp. 299-310, Nov. 2013.

[19] C. R. Barnett, "Pilot Fire Load Survey Carried Out for the New Zealand Fire Protection Association.," Auckland, 1984.

[20] H. W. Yii, "Effect of Surface Area and Thickness on Fire Loads," New Zealand, 2000.

[21] M. Audebert, D. Dhima, M. Taazount, and A. Bouchaï, "Thermo-mechanical behaviour of timber-to-timber connections exposed to fire," Fire Saf. J., vol. 56, pp. 52-64, Feb. 2013.

[22] "Environmental Protection Agency (EPA)," 2015. [Online]. Available: https://www.epa.gov/science-and-technology/substances-and-toxics-science.

[23] C. L. Chow and W. K. Chow, "Heat release rate of accidental fire in a supertall building residential flat," Build. Environ., vol. 45, no. 7, pp. 1632-1640, Jul. 2010.

[24] T. Lennon and D. Moore, "The natural fire safety concept-full-scale tests at Cardington," Fire Saf. J., vol. 38, no. 7, pp. 623-643, Nov. 2003. 
[25] K. M. G. Chen, "Analysis of Semi-Rigid Connections Subject to Fire Loads in a Steel Framework," University of Waterloo, 2010.

[26] N. Ocran, "Technical Note 4," Technical Note 4, 2014.

[27] B. Merci and M. Shipp, "Smoke and heat control for fires in large car parks: Lessons learnt from research?," Fire Saf. J., vol. 57, pp. 3-10, Apr. 2013.

[28] C. Lai, K.-J. Chen, C.-J. Chen, C.-T. Tzeng, and T.-H. Lin, "Influence of fire ignition locations on the actuation of smoke detectors and wet-type sprinklers in a furnished office," Build. Environ., vol. 45, no. 6, pp. 1448-1457, Jun. 2010.

[29] N. Johansson, "Fire Dynamics of Multi-Room Compartment Fires," Lund University, 2015. 